Document downloaded from:

http://hdl.handle.net/10251/52676

This paper must be cited as:

SARA PERALES MOMPARLER; Hernández Crespo, C.; Vallés Morán, FJ.; Martín Monerris, M.; Andrés Doménech, I.; Andreu Álvarez, J.; Jefferies, C. (2014). SuDS efficiency during the start-up period under Mediterranean climatic conditions. CLEAN - Soil, Air, Water. 42(2):178-186. doi:10.1002/clen.201300164.

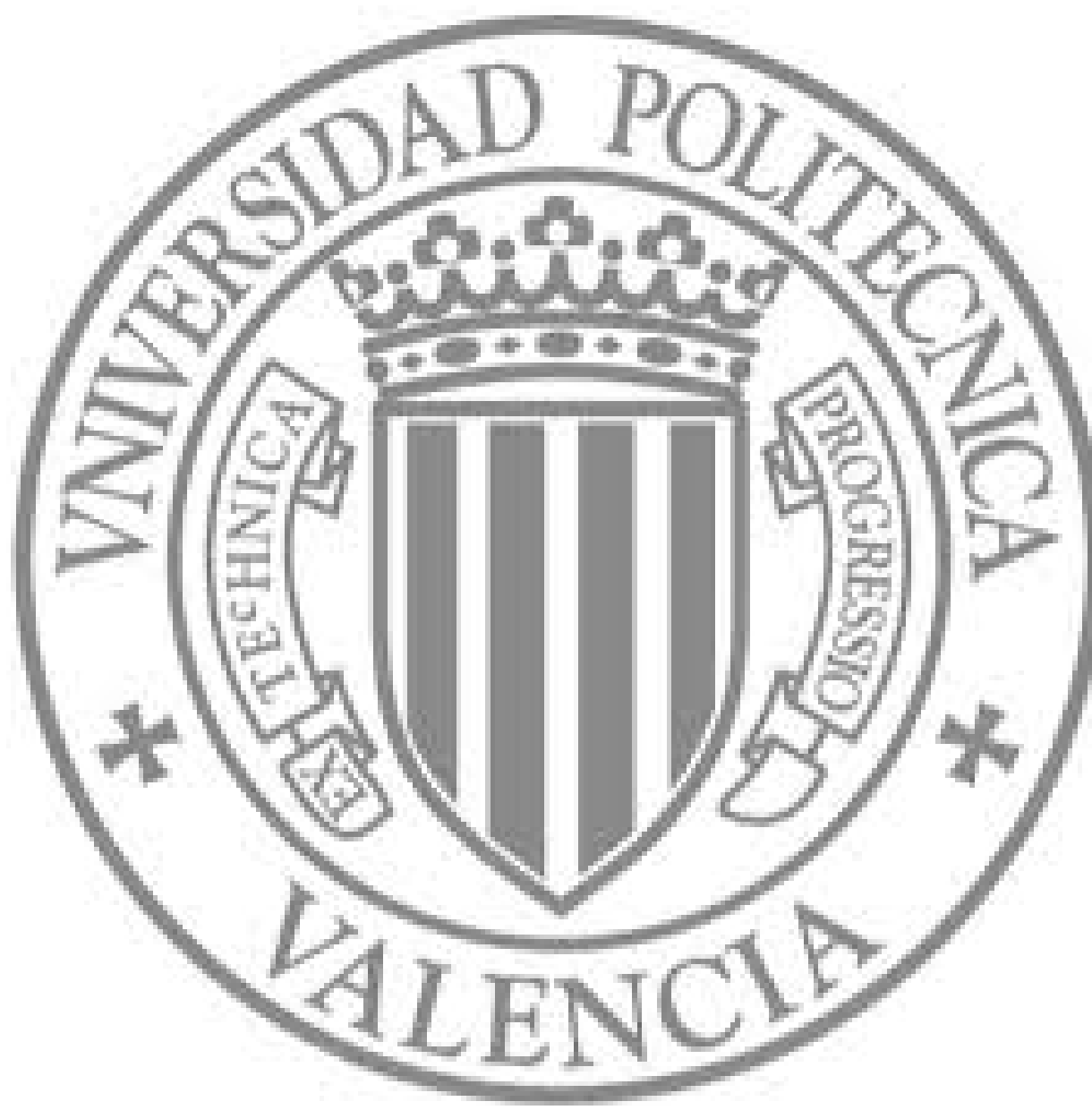

The final publication is available at

http://dx.doi.org/10.1002/clen.201300164

Copyright Wiley 


\title{
SuDS efficiency during the start-up period under Mediterranean climatic conditions
}

\author{
Sara Perales-Momparler ${ }^{(1)}$, Carmen Hernández-Crespo ${ }^{(2)}$, Francisco Vallés-Morán ${ }^{(2)}$, Miguel \\ Martín $^{(2)}$, Ignacio Andrés-Doménech ${ }^{(2)}$, Joaquín Andreu Álvarez ${ }^{(2)}$, Chris Jefferies ${ }^{(3)}$ \\ ${ }^{(1)}$ PMEnginyeria. Avda. del Puerto, 180- 1B. 46023 Valencia. Spain. \\ ${ }^{(2)}$ Instituto Universitario de Ingeniería del Agua y Medio Ambiente (IIAMA). Universitat \\ Politècnica de València. Cno. de Vera s/n. 46022. Valencia. Spain. \\ (3) University of Abertay Dundee. Bell Street. Dundee DD1 1HG. Scotland. UK.
}

Correspondence: Ignacio Andrés-Doménech. Instituto Universitario de Ingeniería del Agua y Medio Ambiente (IIAMA). Universitat Politècnica de València. Cno. de Vera s/n. 46022. Valencia.Spain. E-mail: igando@hma.upv.es

\begin{abstract}
Abbreviations: BMP, Best management practice; $\mathbf{B O D}_{5}$, Five day biological oxygen demand; COD, Chemical oxygen demand; DO, Dissolved oxygen; HRT, Hydraulic retention time; SuDS, Sustainable drainage systems; TN, Total nitrogen; TP, Total phosphorus; TSS, Total suspended solids; VSS, Volatile suspended solids.
\end{abstract}

Keywords: Mediterranean climate, start-up period, sustainable drainage systems, wash-off, water quality. 


\section{Abstract}

This paper presents the performance of a number of sustainable drainage systems (SuDS) in the city of Xàtiva in the Valencia Region of Spain relatively soon after their construction. The systems studied comprise two roadside swales, one detention basin receiving runoff from one of the swales and one green roof to a school. The SuDS were installed under an EU LIFE+ project intended to demonstrate their practicability, application and behaviour under Mediterranean rainfall conditions. Most of the systems installed were in new developments but the green roof was retrofitted to a school within Xàtiva which is a dense urban area. Full flow monitoring was undertaken and spot samples were taken to give a preliminary assessment of water quality performance. The early results presented in the paper demonstrate the effectiveness of the systems under typical Mediterranean conditions which comprise intense rainfall from September to December and little or no precipitation at other times of the year. It is concluded that SuDS can be effectively introduced in the Mediterranean region of Spain.

\section{Introduction}

Sustainable drainage systems (SuDS) were introduced in Northern Europe and the United States to address deteriorating water qualities in lakes, rivers and groundwater caused principally by urban and related developments. Notable applications in the USA, where they are termed structural stormwater BMPs, are to be found in Florida (lake and groundwater quality), Maryland (water quality in Chesapeake Bay) and Colorado (preservation of flows in small streams). In Germany many regions require SuDS on new developments and highways to protect groundwater quality, while in Sweden and Scotland, the driver for SuDS is the quality of rivers and lakes [1, 2].

A wide range of types of SuDS are available to the city and water planner. Some are easier to locate close to buildings and roads (Higher up the treatment train), others provide greater amounts of treatment and storage while others fit better into local landscapes, providing more habitat. The SuDS triangle (quantity/quality/amenity) is used to illustrate the balance that must be met [1].

It is not appropriate to provide an exhaustive list of SuDS in this paper, but source control systems include green roofs, soakaways, permeable paving systems and roadside swales; site controls include detention basins and infiltration systems, and regional controls comprise ponds and wetlands.

It is now realised that SuDS address several agendas in addition to that of receiving water quality. Increasing knowledge of climate change has sharpened concerns that rainfall may change both in terms of average rainfall, with effects on water resources, and rainfall intensities which may cause greater amounts of flooding. Since the philosophy of SuDS is to provide space for surplus water within the urban area, additional resilience to floods and droughts can thus be built automatically into SuDS. The storage gives a measure of protection against flooding through attenuation but it also can provide a source of water for re-use within the city. A further issue is the amount of energy used in the water and drainage sector, and by 
preventing rainwater from flowing into the drains, there will be less pumping and less treatment to provide water for irrigation and toilet flushing.

In a scientific and engineering sense, the performance of a SuDS component depends on a range of local conditions such as the construction of the component, soil types and rainfall regime and depends on the local climate. However, to operate in the long term, SuDS must be fully integrated into the city framework and local operational practices and the arrangements for SuDS in a very dense Spanish city will be very different from those in a city with less impermeable area and different operational practices.

Transposition of the EU Water Framework Directive [3] to the Spanish regulatory framework has introduced the principle of achieving a good ecological status to River Basin Management Plans highlighting a lack of regulation, amongst others, in relation to combined sewer overflows (CSOs). A recent legislative instrument [4] establishes new procedures for obtaining or maintaining discharge permits for both stormwater and combined sewer systems. Even though best available (and affordable) practices and technical knowledge are specified, the legislation requires future technical rules to be developed. Nevertheless, article 259 of [4] indicates that new urban developments should incorporate measures to reduce runoff entering the drainage system. It would be desirable that the technical rules should also embody recent European Commission guidelines for water management which promote the use of SuDS [5].

This paper focuses on three types of SuDS: a green roof, two roadside swales and an infiltration basin. By covering roof areas with soil and vegetation, green roofs can achieve numerous benefits. Stormwater runoff can be reduced and attenuated so that the urban water balance approaches a natural state [6]. Moreover, there are other collateral benefits including thermal improvements, indoor noise, air pollution reduction and social and amenity benefits. By using swales, the total runoff volume is reduced through infiltration and storage; peak flows are lowered also through infiltration and the flow is retarded by increased channel roughness [7]. The performance of detention basins is also improved when located on a soil where infiltration is possible.

Two matters are of specific interest in this work: (i) the adequacy of SuDS in the Mediterranean context, and (ii) their performance during the start-up period, i.e., during the months just after their construction. In contrast to Northern Europe, experience of SuDS in Mediterranean regions over the last decade is still poor $[2,8]$. Recently in Spain real effort has been put in to develop expertise and guidelines $[9,10,11]$ and some sites have already been implemented mainly in the northern coastal region [12] but also in Barcelona, Madrid and the Valencia region [13]. The transition to this new approach to manage urban stormwater has been started in Spain but water planners and stakeholders are still reluctant to incorporate these solutions because their hydraulic and quality performances are still not well demonstrated locally, highlighting the need for experiments and monitoring under Mediterranean climatic conditions.

The influence of the start-up period on the hydraulic performance of green roofs is poorly addressed in the reviewed literature and this paper analyses the response of SuDS during their 
implementation period. However, since both the vegetation and the substrate undergo major changes with time, it can be expected that the age of the infrastructure will influence the runoff dynamics [6]. The same a priori conclusions must apply to swales and infiltration basins since the age of vegetation also influences the soil infiltration capacity.

In addition to their ability to retain water and the corresponding benefits to drainage management, green roofs have the ability to remove pollutants; however, the evidence for the effectiveness of pollutant removal is mixed [6]. The use of fertilizers, the composition of the soil, type of vegetation, pollutants, atmospheric pollution, among others, are all factors, some extremely site specific, that affect the quality of runoff from green roofs [14].

Sedimentation in grass swales is the principal treatment mechanism with filtration playing a minor but highly effective role [15] in reducing total suspended solids [16]. In this type of study, analysis of nutrients is also important due to the importance of nutrient control for many water bodies. Frequently, depending on the rainfall intensity, flooding from sewers occurs and significant nutrients loads are discharged into receiving water bodies. High variability in nutrient removal is observed in field studies for this type of SuDS [16].

It has also been shown that the pollutant mass washed off the surface of the contributing catchment during a storm event depends on the number of antecedent dry days [17] whilst others have found that the maximum rainfall intensity significantly affected pollutant concentrations [18]. Low correlation coefficients have been found between rainfall, rainfall intensity, temperature, and antecedent dry period with particulate pollutants, whereas the coefficient between rainfall duration and particulate pollutants was positive and relatively large [19].

During this start-up period, the vegetation is establishing and soils are still not well-compacted so the quality performance is not what is to be expected in the long term. The next section describes the overall framework of the AQUAVAL project in which this research was developed. The pilot sites in Xàtiva are then described as well as the quantity and quality monitoring programme. Section 3 deals in detail with the results, analyzing the performance achieved in each pilot during the start-up period. Concluding remarks are finally drawn in section 4. 


\section{Materials and Methods}

\subsection{The AQUAVAL project}

AQUAVAL ("The efficient management of rain water in urban environments") is a project funded by the EU LIFE+ Community Initiative whose main target is to find, implement and promote innovative solutions to decrease the impacts of developments on quantity and quality of urban runoff (e.g. flooding, CSOs, pollution, drought, etc.) within the Valencia Region of Spain. The project started on $1^{\text {st }}$ January 2010 , and is due to conclude by the end of September 2013. The project comprises the construction and monitoring of pilot SuDS as an important step towards the required change of paradigm. The scope of the project includes production of sustainable urban stormwater management plans and policies with the aim of making drainage infrastructure versatile and able to cope with the effects of climate change.

The municipality of Xàtiva is a municipal member of the AQUAVAL project in which the guiding principle is to ensure that rainwater management is included in water and land use planning, making the best use of landscape and morphology in order to integrate water infrastructure using SuDS, adding social and environmental values. Pilot SuDS locations in Xàtiva were chosen in places that have the ability to alleviate current problems of frequent flooding and CSO discharge, are typical of the Mediterranean region with its characteristic long hot droughts broken by high intensity storms, and is a dense and highly impermeable city with a combined sewer system.

\subsection{Site descriptions}

Xàtiva is located in the western Mediterranean on the Spanish coast. Its climate is Mediterranean, mild and semi-arid. The average temperature is around $16^{\circ} \mathrm{C},\left(10^{\circ} \mathrm{C}\right.$ in January and $27^{\circ} \mathrm{C}$ in August) with extreme maxima which can reach $47^{\circ} \mathrm{C}$ in summer. The average annual rainfall is close to $690 \mathrm{~mm}$, with very strong seasonality (Spanish Meteorological Agency, AEMET). Rain storms are usually concentrated in autumn, typically with very high peak intensities. This climate regime differs significantly from that of more northern and temperate climates where SuDS originated, justifying the value of properly monitored pilot projects.

Two of the new SuDS were in a new urban area to the north of Xàtiva and one was in the city centre. Site 1 (3859'47.13"N 031'53.67' W) provides a $170 \mathrm{~m}^{3}$ storage volume (Figure 1). This volume manages runoff from $1900 \mathrm{~m}^{2}$ of the adjacent road pavement and around 11100 $\mathrm{m}^{2}$ from the Sports City (a new sports complex). It comprises a $1.1 \mathrm{~m}$ wide (on average), $75 \mathrm{~m}$ long swale which is linked to an infiltration basin $\left(50 \mathrm{~m}^{2}\right.$ base area), both retrofitted within the Sports City. Overflows occur to a nearby stormwater pipe.

Site 2 (38959'25.21" $\left.\mathrm{N} 0.32^{\prime} 04.80^{\prime \prime} \mathrm{W}\right)$ is located between a new urban development and a section of a ring road that had no drainage infrastructure and contributed to flooding of an industrial area downhill (Figure 2). A $1.7 \mathrm{~m}$ wide swale has been constructed in the verge of the road, replacing the flat green area that was in the original plans. Four pedestrian crossings and 5 transverse structures act as barriers of low permeability to slow the flow. The swale is divided in two sections of $275 \mathrm{~m}$ and $95 \mathrm{~m}$ length respectively, and there are two emergency spillways to direct overflow to a stormwater pipe nearby. The monitoring focused on the 
longest section with a total catchment area of $7000 \mathrm{~m}^{2}$ (both public and private road pavement) and a storage volume of $218 \mathrm{~m}^{3}$.

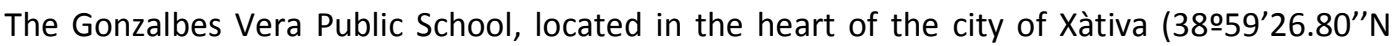
031'04.31'”W), was chosen as site 3 (Figure 3). $475 \mathrm{~m}^{2}$ of the roof has been retrofitted with a green roof and the playground has been re-paved with porous concrete. The substrate of the vegetated roof has a density of $1060 \mathrm{~kg} \mathrm{~m}^{-3}$ and is rich is organic matter (29\%), total nitrogen $(0.27 \%)$ and phosphorus $\left(0.57 \%\right.$ as $\left.\mathrm{P}_{2} \mathrm{O}_{5}\right)$. The depth of substrate is $10 \mathrm{~cm}$ and it is planted with a variety of Sedum. Monitoring activities reported here comprised water quantity and quality measurements from a section of the new green roof $\left(218 \mathrm{~m}^{2}\right)$ as well as runoff from the remainder of the conventional roof which was untouched $\left(107 \mathrm{~m}^{2}\right)$.

The three SuDS systems were commissioned in August 2012, and the monitoring equipment was installed the following month.

\subsection{Monitoring of quantity and quality variables}

From a quantitative point of view, the main hydraulic variable of interest is the rate of overflow spills from each of the SuDS into the receiving sewer. This flow was measured with different equipment, depending on the type of SuDS and on the installation characteristics. Discharges from the infiltration basin and from the roadside swale were measured with $\mathrm{V}$ notch weirs $\left(90^{\circ}\right)$, the hydraulic head over the vertex being recorded by mean of a level probe. Sewer flows were measured with ultrasonic flow meters that record both depth and flow velocity in the sewer. Finally, the flow rate through the downpipes of the green roof was monitored with tipping bucket flow gauges. In this case, every time the bucket tips, an electrical pulse is recorded. All this equipment was calibrated in the laboratory, especially the tipping buckets to know accurately the volume of water causing each tip. Finally, dataloggers recorded the outputs from the level sensors, ultrasonic flow meters and tipping buckets.

Level probes at 1 and 2 were Mercoid SBLT2-5-40-ETFE submersible level transmitters with a measuring range up to $3.5 \mathrm{~m} \mathrm{(} \pm 9 \mathrm{~mm}$ ). Each transmitter was connected to a Lufft OPUS 20 LF8120.30 datalogger with external sensors (temperature, humidity and analog input 4/20 $\mathrm{mA})$. Bühler Montec Xytec7050 free surface ultrasonic flow monitors devices with dataloggers were also located at 1 and 2 .

A digital output signal is activated if the monitored variable exceeds a defined threshold. When this occurs the device sends an alert SMS to selected cellular phones. A minimum number of tips for the tipping bucket in the conventional roof downpipe was defined as the threshold so that the related rainfall depth produced runoff in the system. Water quality samples were generated by the trigger and had to be collected. Finally, hourly rainfall data in Xàtiva was collected by the Spanish Meteorological Agency (AEMET). Table 1 summarises the equipment installed and the monitoring periods. Quantity sampling points are indicated in Figures 1, 2 and 3.

A total of nine water sampling points were used (Figures 1,2 and 3). There were three sampling points at sites 1 and 2 corresponding to the two inputs and the output from the swales to the sewer system. For site 1 (Figure 1 ) they were from the Sports City (11) and the 
adjacent roadway (12). For the North Ring Road (Figure 2) the inflows were from the residential area (21) and the adjacent North Ring Road itself (22). In both systems the water was collected using two litre plastic bottles with one bottle per sampling point per event. The bottles were filled at the beginning of each rain event. Accordingly, the water quality corresponded to the first wash off. The output bottles (13 and 23) were filled only if there were discharges and, consequently, the water quality was the result of all the processes (sedimentation of total suspended solids, sorption, biodegradation, volatilization) that occurred inside the swales during the event, whose performance depends on hydraulic retention time (HRT) and other environmental factors. However, when HRT is low, the output is mainly related to the input pollutograph as there is no time for treatment other than sedimentation.

Samples from both parts of the school roof, vegetated (31) and conventional (32), were collected in four bottles linked to the tipping buckets (two bottles per tipping bucket). The boxes where the buckets were placed were designed to allow the bottles to be filled consecutively at the start of the rain event and thus, there were a total of four samples per event. Finally, one bottle was located on the roof to collect rain water and atmospheric deposition (33).

Water samples were analysed for organic matter, nutrients and solids. Chemical oxygen demand (COD), total nitrogen (TN) and total phosphorus (TP) were analysed using a Spectroquant ${ }^{\circledR}$ Analysis System by Merck. Five day biological oxygen demand $\left(\mathrm{BOD}_{5}\right)$ was measured using OxiTop ${ }^{\circledR}$. Total suspended solids (TSS) and volatile suspended solids (VSS) were determined according to the Standard Method for Examination for Water and Wastewater [20]. Turbidity was measured with a turbidimeter TN100-Eutech Instruments. In addition, the following were measured in situ: water temperature, $\mathrm{pH}$, conductivity and dissolved oxygen (DO) all with WTW $^{\circledR}$ probes. The events monitored for water quality are indicated in Table 2.

\section{Results and discussion}

\subsection{Rainfall pattern during the start-up period}

Monitoring began at the end of September 2012 with the most torrential event recorded during the autumn of 2012 (event 1 in Table 2) and it was the first significant period of rainfall following the construction of the SuDS. This meant that the start-up period began with relatively extreme heavy rainfall conditions: $92 \mathrm{~mm}$ in 3 days; with approximately $50 \%$ of this amount falling between $12: 00$ and 14:00 on September 28 . The previous dry period was close to one month so that pollutant accumulation on the contributing surfaces was likely to be significant. After this torrential event, 8 additional episodes were recorded during the following three months. Table 2 summarizes key features of each event recorded: starting and ending dates, previous dry inter-event time, duration and rainfall depth. 


\subsection{Hydraulic performance}

Several variables relating to the hydraulic performance of each SuDS have been deduced for each pilot. For sites 1 and 2, overflows from the basin to the receiving sewer were characterized by the spill volume and peak flow. Hydrographs in the receiving sewer were monitored so that they could be compared with the swale overflows to assess differences between peak flows and their time of occurrence. Finally, runoff volumes and peak flows at site 3 were obtained for both the conventional roof and the green roof. The hydrograph of the receiving sewer to which both downpipes were connected was also monitored. A summary of all these results is shown in Table 3. Results for the green roof 3 were only obtained for event 8 and 9 as the reed switch of the tipping bucket was initially unreliable, although it was possible to collect water quality samples.

Runoff volumes entering the corresponding SuDS were calculated for each site and each event, runoff volumes being deduced from rainfall event depths, tributary areas and averaged runoff coefficients (Table 3). All flow during events 3, 4, 5, 7 and 8 was retained at sites 1 and 2 which both incorporate SuDS with both storage and infiltration capacity. It is concluded that runoff produced by rainfall events of depth up to $23.8 \mathrm{~mm}$ are completely retained at both locations. Event 2, with a rainfall depth of $35.4 \mathrm{~mm}$ produced overflow at both sites. Without the SuDS, the threshold before runoff occurred would be around 1-2 $\mathrm{mm}$ rainfall (corresponding to the paved areas close to 1 and 2).For the green roof, results shown in Table 3 highlight that the runoff threshold in this case is much lower (events 8 and 9 overflowed with 9.4 and $4.6 \mathrm{~mm}$ of rainfall respectively), as the storage capacity of this site is very low.

Hydrographs and water levels monitored at 1 and 2 show in detail the hydraulic performance of these SuDS. Figure 4 represents the hydraulic behavior of site 1 during event 2 . This event was chosen among the huge amount of data collected and processed during the project, because it highlights properly the conclusions reached. Overflow occurs when the water level upstream exceeds the weir vertex level. Figure 5 shows results for the same event at the Ring Road site. Since the receiving sewer hydrograph was also monitored at this location, the results are more conclusive. It will be observed that each time the swale overflows (twice in event 2), the peak flow of the spill flow occurs later than the sewer peak flow. This highlights the attenuating effect produced by the swale. Spill volumes during event 2 can also be calculated: $54.1 \mathrm{~m}^{3}$ for 1 and $33.4 \mathrm{~m}^{3}$ for 2 . The spill volumes were compared with the infrastructure storage volumes $\left(170 \mathrm{~m}^{3}\right.$ and $218 \mathrm{~m}^{3}$ respectively). The result shows that spill volumes were smaller than those detained.

The contributing area infiltration basin 1 (including the swale and the basin) is $13000 \mathrm{~m}^{2}$ and its averaged runoff coefficient (ratio between rainfall volume and runoff volume finally produced, related to soil type and land use) 0.76 ; the side roadway and the swale area that contribute to 2 runoff is $7000 \mathrm{~m}^{2}$ with an averaged runoff coefficient 0.93 ; the conventional roof is $107 \mathrm{~m}^{2}$ while the green roof is $218 \mathrm{~m}^{2}$. In both cases in 3, the runoff coefficient must be set to 1 as the tributary area is exactly the same as the roof area.

The volumetric efficiency (VE) was calculated as 
$\mathrm{VE}=[1-\mathrm{SV} / \mathrm{RV}] \times 100$

where $\mathrm{SV}$ is the spill volume and RV the runoff volume. VE shows the ratio between the runoff managed by the infrastructure (either detained or infiltrated or both) and the total runoff produced by the contributing area. Thus, a VE of $80 \%$ means that only $20 \%$ of the event runoff volume produced overflow. The results are summarized in Table 4 where the efficiencies obtained are always greater than $63 \%$ for 1 and 2 . For events 3, 4, 5, 7, 8 and 9, the overall runoff was managed by the infrastructure giving efficiencies of $100 \%$.

The efficiency for the first result for the green roof (event 8 ) was poor (52\%). This result is directly related to the start-up conditions with vegetation still not well developed, causing the retention capacity of the green roof not to be fully available. Moreover, the substrate was saturated as there had been two events following the long event of mid-November (event 6). The volumetric efficiency for the green roof increased to $73 \%$ for the last recorded episode (event 9). The main reason for this significant increase may be the preceding dry period of one month which was conducive to vegetation grow and soil drying. The performance of the green and conventional roofs was only measurable for events 8 and 9 due to the unreliability of some of the equipment. For event 8 , the overflow volume for the conventional roof was 5.33 $\mathrm{mm}$ while for the green roof only $4.50 \mathrm{~mm}$ overflowed ( $16 \%$ less). For event 9 , the figures were $3.18 \mathrm{~mm}$ and 1.24 respectively (61\% less). These results show that the hydraulic performance of a green roof can increase significantly with a longer inter-event time.

\subsection{Runoff water quality and SuDS response}

There were two different inputs to the grass swale-infiltration basin system at the Sports City (1): one from the Sports City itself (11) and the other from the adjacent roadway (12) resulting in different rates and qualities of runoff (Figure 6). In most cases observed to date, 12 is the more contaminated of the two runoff inlets, as explained below.

Water quality samples from a total of five storm events were analysed (Table 2). Three events stand out as being very intense (events 1, 2 and 6), the most intense being the first, giving rise to extreme concentrations of TSS (3083 mg. $\left.\mathrm{L}^{-1}\right)$ and COD $\left(1600 \mathrm{mg} \cdot \mathrm{L}^{-1}\right)$ in the wash off of the adjacent roadway (12). These concentrations were very high compared with typical wastewater and are related to the storm intensity and the long antecedent dry period. In this regard, Sansalone et al. [21] showed that annual loads of TSS and COD transported in stormwater runoff from interstate and arterial roadways were approximately equivalent to that from untreated domestic wastewater generated by the population in the same urban area. Sansalone et al. [22] measured high concentrations of suspended solids in runoff from small impervious watersheds, even higher than that measured here. In the subsequent events, input concentrations were noticeably lower, indicating that sediment on the roadway had already been washed off. The values monitored for the later events are compared with values reported for highways runoff by other authors [17]. Relationships $\mathrm{BOD}_{5} / \mathrm{COD}$ were relatively low for every sampling point with mean values of $0.15,0.09$ and 0.16 for 11,12 and 13 respectively, indicating the low biodegradability of organic matter present in the runoff. In site 1 , the average proportion of VSS to TSS was about $15 \%$ showing that the major fraction of solids was inorganic. 
In the two first storm events, the grass swale in site 1 had a small treatment effect, the output sample producing higher TSS concentration than the inputs. This finding can be explained by the extreme intensity of these events which produced soil erosion in the areas surrounding the grass swale and the limited establishment of the vegetation at start-up. In the subsequent events, which were less intense, the output concentrations were lower than inputs. In the last, much smaller, event 9 , the swale retained the overall pollution load because the spill volume was zero (Table 3).

At the North Ring Road swale (site 2) the runoff from sampling point 2 produced generally higher concentrations of pollutants than the second inlet (21) (Figure 7). A similar result was also obtained in pilot zone 1 (Sports City).

As in zone 1, COD and TSS concentrations measured in the roadway inlet (22) in events 1 and 2 were very high. The explanation for these results is again related to the intensity of the storm events and the long antecedent dry period for event 1 . The influence of these factors has been observed by other authors $[17,18]$. In addition, these high loads are also influenced by residues from the construction processes around, recently ended. In the subsequent events, the concentrations of COD and TSS in runoff were much lower.

Data from sampling points 21 and 23 (Figure 7) were scarcer than from 22 principally because the bottles were not filled. This was due to the lower runoff rate to 21 from the residential area. $\mathrm{BOD}_{5}$ analyses for site 2 produced similar results to site 1 with relatively low $\mathrm{BOD}_{5} / \mathrm{COD}$ ratios giving mean values of $0.15,0.08$ and 0.17 for 21,22 and 23 respectively.

The relationship between turbidity and TSS was similar in both zones 1 and 2, giving a good linear correlation $\left(r^{2}>0.9\right)$ and similar turbidity/TSS relationships: around 0.6 for inlet points and 0.9 for the output samples. The study of these types of relationship is useful when considering whether turbidity probes might be installed as complementary devices to monitor pollutographs with fewer samples. The correlations obtained to date are promising in this sense. In site 2 , the proportion of VSS to TSS was around $13 \%$ showing that the major solids fraction is inorganic.

Events, 2, 3 and 6 (Table 2) were monitored for water quality at the school roof (3). Only 3 events were monitored as stated in the planning of the water quality campaign for this period. Runoff quality from both conventional and green roofs was poorer than the rain water (Table 5 ). The water from the vegetated roof was highly brown in colour but clear (turbidity lesser than $20 \mathrm{NTU}$ ). All the measured concentrations were higher, and specially COD much higher, than those for the conventional roof. The organic fraction was very high but was not easily biodegradable: the relationship between $\mathrm{BOD}_{5}$ and $\mathrm{COD}$, a good estimator of biodegradation, was only 0.05 . The presence of organic matter is related to the substrate characteristics. Nutrient concentrations also increased by a factor of 9 for total nitrogen and 15 for total phosphorus after passing through the vegetated layer. However, in the case of total nitrogen, the increase cannot be assigned exclusively to the soil because the concentration of TN also increased by 4 from the conventional roof. Dry deposition of atmospheric nitrogen due to the proximity to a park with a very high birdlife is likely to be responsible for a significant load of TN. These results are similar to those obtained in other studies $[23,24]$, where increases of TP 
concentration were as high as observed here, whereas nitrogen concentrations decreased or, sometimes, increased slightly. The concentrations of suspended solids were also higher than for the rain water.

To date, there have been no significant differences between events because the start-up phase is still ongoing. Additionally, a slow change of concentration over time was observed for event 6: after 100 hours from the first sample, the COD, TN, and conductivity halved but TP increased by $70 \%$. Consequently, during the start-up phase, the vegetated roof increased pollutant concentrations, but when vegetation is well established, they should decrease over time as some references suggest [14].

\section{Conclusions}

Three SuDS sites have been constructed and monitored for the first time in the Mediterranean part of Spain. Two of the sites are new build swales and an infiltration basin and one is a retrofit green roof on an existing school. The hydrological and water quality results for swales and the basin clearly show significant attenuation of flows, volumes and concentrations. Outflow from the swales only occurred during three out of the nine events monitored and the spill events included an event with a maximum rainfall intensity of $45 \mathrm{~mm}$ in a two hour period. Extremely high pollutant concentrations (and by inference, loads) were observed during the first rain event after commissioning. The high loads were believed to be due to a combination of residues from the construction process and from the very long antecedent dry period before the first event observed. Moreover, high rain intensities made this situation even worse because of a more powerful wash-off, although these data are believed to be typical of the Mediterranean climate. To date, water quality from the green roof has been worse than from the conventional roof owing to the high organic matter and nutrients in the substrate. However, when the vegetation matures, these results are expected to be better. Finally, the AQUAVAL project is also producing social benefits since local authorities are confident of their results and they are even considering retrofitting more SuDS infrastructure.

\section{Acknowledgements}

The research described in this paper has been carried out under the Life+ programme research project "AQUAVAL Sustainable Urban Water Management Plans, promoting SUDS and considering climate change, in the province of Valencia" (Life08ENV/E/000099), supported by ERDF funding of the European Union.

The authors have declared no conflict of interest. 


\section{References}

[1] B. Woods-Ballard, R. Kellagher, P. Martin, C. Jefferies, R. Bray and P. Shaffer. The SUDS Manual. CIRIA C697, London. 2007.

[2] J. C. Deutsch, M. Revitt, B. Ellis and L. Scholes. Review of the Use of Stormwater BMPs in Europe. DAYWATER, Report 5.1. 2003.

[3] Directive 2000/60/EC of the European Parliament and of the Council establishing a framework for the Community action in the field of water policy, Official Journal (OJ L 327). 2000.

[4] Real Decreto 1290/2012, de 7 de septiembre, por el que se modifica el Reglamento del Dominio Público Hidráulico, aprobado por el Real Decreto 849/1986, de 11 de abril, y el Real Decreto 509/1996, de 15 de marzo, de desarrollo del Real Decreto-ley, de 28 de diciembre, por el que se establecen las normas aplicables al tratamiento de las aguas residuales urbanas. $B O E$ no 227. 2012.

[5] European Commission. Guidelines on best practices to limit, mitigate or compensate soil sealing, SWD(2012) 101 final. 2012.

[6] J. Czemiel Berndtsson. Green Roof Performance towards Management of Runoff Water Quantity and Quality: A Review. Ecol Eng. 2010, 36 (4), 351-360.

[7] A. P. Davis, J.H. Stagge, , E. Jamil, H. Kim, Hydraulic performance of grass swales for managing highway runoff, Wat. Res. 2012, 46, 6775-6786.

[8] S. Perales and I. Andrés-Doménech. Los sistemas urbanos de drenaje sostenible: una alternativa a la gestión del agua de lluvia, Revista Técnica de Medio Ambiente C\&M Publicaciones. 2008, 124 (Enero - Febrero 2008), p. 92-104.

[9] A. Casal-Campos, C. Jefferies and S. Perales-Momparler. Selecting SUDS in the Valencian Region of Spain, Wat. Pract. \& Tech. 2012, 7 (1). doi:10.2166/wpt.2012.001.

[10] J. Puertas Agudo, J. Suárez López, J. Anta Álvarez. Gestión de las aguas pluviales: implicaciones en el diseño de los sistemas de saneamiento y drenaje urbano, Ministerio de Fomento, CEDEX, Centro de Estudios Hidrográficos, Monografías; M-98. 2008, ISBN 978-847790-475-5.

[11] J. J. Rodríguez Sánchez, A. Díaz Martínez. Guía técnica de diseño y gestión de balsas y otros dispositivos de retención de contaminantes en carreteras, Centro de Publicaciones, Ministerio de Fomento, CEDEX, Centro de Estudios de Técnicas Aplicadas. Manuales y recomendaciones; $R$-18. 2009, ISBN 978-84-7790-486-1.

[12] E. Gomez-Ullate, E. Castillo-Lopez, D. Castro-Fresno and J.R. Bayon, Analysis and Contrast of Different Pervious Pavements for Management of Storm-Water in a Parking Area in Northern Spain, Water Resources Management. 2011 , 25 (6), 1525-1535. 
[13] D. Castro-Fresno, V. C. Andrés-Valeri, L. A. Sañudo-Fontaneda, Rodriguez-Hernandez, J. Sustainable Drainage Practices in Spain, Specially Focused on Pervious Pavements. Water 5 , 2013 (1), 67-93. http://www.mdpi.com/2073-4441/5/1/67.

[14] D. B. Rowe. Green roofs as a means of pollution abatement. Environ. Pollut. 2011, 159, 2100-2110.

[15] A. Deletic, Modelling of Water and Sediment Transport over Grassed Areas, J. Hydrol. 2001, 248, 168-182.

[16] J. H. Stagge, A. P. Davis, E. Jamil, H. Kim Performance of grass swales for improving water quality from highway runoff, Wat. Res. 2012, 46, 6731-6742

[17] L.H. Kim, K. D. Zoh, S. M. Jeong, M. Kayhanian, M. K. Stenstrom, Estimating Pollutant Mass Accumulation on Highways during Dry Periods, J. Environ. Eng. 2006, 132, 985-993.

[18] I. M. Broodie, P. K. Dunn, Commonality of Rainfall Variables Influencing Suspended Solids Concentrations in Storm Runoff from Three Different Urban Impervious Surfaces, J. Hydrol. 2010, 387, 202-211.

[19] X. J. Zuo, D. F. Fu, H. Li, R. P. Singh, Distribution Characteristics of Pollutants and Their Mutual Influence in Highway Runoff, Clean-Soil Air Water, 2011, 39 (10), 956-963.

[20] APHA, Standard methods for the examination of water and wastewater, 17th ed., American Publish Health Associaton. Washington, DC (USA). 1991.

[21] J. J. Sansalone, J. M. Koran, J.A. Smithson, S. G. Buchberger, Physical Characteristics of Urban Roadway Solids Transported during Rain Events, J. Environ. Eng. 1998, 125 (5), 427-440.

[22] J. J. Sansalone, M. C. Chad, Fisrt Flush Concepts for Suspended and Dissolved Solids in Small Impervious Watersheds, J. Environ. Eng. 2004, 130, 1301-1314.

[23] J. Czemiel Berndtsson, T. Emilsson, L. Bengtsson, The Influence of Extensive Vegetated Roofs on Runoff Water Quality. Sci. Tot. Environ. 2006, 355, 48-63

[24] K. Vijayaraghavan, U.M. Joshi, R. Balasubramanian, A field study to evaluate runoff quality from green roofs. Wat. Res. 2012, 46, 1337-1345. 
Figure legends

Figure 1. Site 1. Infiltration basin. Photo (left) and monitoring points scheme (right).

Figure 2. Site 2. Roadside swale. Photo (left) and monitoring points scheme (right).

Figure 3. Site 3. Green roof. Photo (left) and monitoring points scheme (right).

Figure 4. Hydraulic performance for site 1 during event 2.

Figure 5. Hydraulic performance for site 2 during event 2.

Figure 6. Results of quality variables for monitored rainfall events in Sports City green swale (11: Sports City runoff, 12: roadway runoff, 13: green swale output). Columns indicate all rainfall events. The $\mathrm{X}$-axis is time scaled.

Figure 7. Results of quality variables for monitored rainfall events in the North Ring Road grass swale (21: residential area runoff, 22: roadway runoff, 23: grass swale output). Columns indicate all rainfall events. The $\mathrm{X}$-axis is time scaled. 
Table 1. Monitoring of quantity variables.

\begin{tabular}{|c|c|c|c|c|c|c|}
\hline Zone & 1 & \multicolumn{2}{|c|}{2} & \multicolumn{3}{|c|}{3} \\
\hline Devices & $\begin{array}{c}\text { Double V Notch } \\
\text { weir + level } \\
\text { sensor }\end{array}$ & $\begin{array}{l}\text { V Notch weir } \\
+ \text { level sensor }\end{array}$ & $\begin{array}{l}\text { Ultrasonic } \\
\text { flow meter }\end{array}$ & $\begin{array}{l}\text { Tipping } \\
\text { bucket }\end{array}$ & $\begin{array}{l}\text { Tipping } \\
\text { bucket }\end{array}$ & $\begin{array}{l}\text { Ultrasonic } \\
\text { flow meter }\end{array}$ \\
\hline $\begin{array}{c}\text { Monitored } \\
\text { variable }\end{array}$ & $\begin{array}{c}\text { Level over the } \\
\text { weir }\end{array}$ & $\begin{array}{l}\text { Level over the } \\
\text { weir }\end{array}$ & $\begin{array}{c}\text { Level + flow } \\
\text { velocity }\end{array}$ & $\begin{array}{l}\text { Tipping } \\
\text { pulses }\end{array}$ & $\begin{array}{l}\text { Tipping } \\
\text { pulses }\end{array}$ & $\begin{array}{c}\text { Level + flow } \\
\text { velocity }\end{array}$ \\
\hline $\begin{array}{l}\text { Output } \\
\text { results }\end{array}$ & $\begin{array}{c}\text { Flow discharge } \\
\text { from the } \\
\text { infiltration } \\
\text { basin }\end{array}$ & $\begin{array}{l}\text { Flow } \\
\text { discharge } \\
\text { from the } \\
\text { roadside } \\
\text { swale }\end{array}$ & $\begin{array}{l}\text { Sewer } \\
\text { flow }\end{array}$ & $\begin{array}{l}\text { Flow } \\
\text { discharge } \\
\text { from the } \\
\text { existing roof }\end{array}$ & $\begin{array}{l}\text { Flow } \\
\text { discharge } \\
\text { from the } \\
\text { green roof }\end{array}$ & $\begin{array}{l}\text { Sewer } \\
\text { flow }\end{array}$ \\
\hline $\begin{array}{c}\text { Monitoring } \\
\text { starting date }\end{array}$ & $27 / 09 / 2012$ & $19 / 09 / 2012$ & $19 / 09 / 2012$ & $18 / 10 / 2012$ & $18 / 10 / 2012$ & $18 / 10 / 2012$ \\
\hline
\end{tabular}

Table 2. Key features for rainfall recorded events.

\begin{tabular}{cccccccc}
\hline Event & Start date / time & End date / time & $\begin{array}{c}\text { Previous } \\
\text { dry inter- } \\
\text { event } \\
\text { time } \\
\text { (days) }\end{array}$ & $\begin{array}{c}\text { Event } \\
\text { duration } \\
\text { (h) }\end{array}$ & $\begin{array}{c}\text { Event } \\
\text { rainfall } \\
\text { depth } \\
\text { (mm) }\end{array}$ & Water Quality \\
& & & & & & & Monitoring \\
\hline 1 & $27 / 09 / 201212: 00$ & $30 / 09 / 201212: 00$ & 28.50 & 72 & 92.0 & 1 & 2 \\
2 & $12 / 10 / 201217: 00$ & $13 / 10 / 201200: 00$ & 12.75 & 7 & 35.4 & 1 & 2 \\
3 & $19 / 10 / 201221: 00$ & $21 / 10 / 201212: 00$ & 6.87 & 39 & 23.8 & 1 & 2 \\
4 & $25 / 10 / 201205: 00$ & $25 / 10 / 201219: 00$ & 3.71 & 14 & 5.4 & & 3 \\
5 & $30 / 10 / 201213: 00$ & $31 / 10 / 201206: 00$ & 4.75 & 17 & 5.4 & & \\
6 & $09 / 11 / 201206: 00$ & $15 / 11 / 201217: 00$ & 9.00 & 155 & 199.6 & 1 & 2 \\
7 & $17 / 11 / 201221: 00$ & $19 / 11 / 201203: 00$ & 2.17 & 30 & 8.0 & & 3 \\
8 & $26 / 11 / 201220: 00$ & $27 / 11 / 201216: 00$ & 7.71 & 20 & 9.4 & & 2 \\
9 & $25 / 12 / 201223: 00$ & $26 / 12 / 201206: 00$ & 28.29 & 7 & 4.6 & 1 & 2 \\
\hline
\end{tabular}

Table 3. Hydraulic variables of each pilot performance for each recorded event.

\begin{tabular}{ccccccccccc}
\hline Site & $\begin{array}{c}1 \\
\text { Spill } \\
\text { volume }\end{array}$ & $\begin{array}{c}1 \\
\text { Spill } \\
\text { peak } \\
\text { flow }\end{array}$ & $\begin{array}{c}\text { Spill } \\
\text { volume }\end{array}$ & $\begin{array}{c}2 \\
\text { Spill } \\
\text { peak } \\
\text { flow }\end{array}$ & $\begin{array}{c}\text { Sewer } \\
\text { peak } \\
\text { flow }\end{array}$ & $\begin{array}{c}\text { Conv. } \\
\text { Roof } \\
\text { peak } \\
\text { flow }\end{array}$ & $\begin{array}{c}\text { Conv. } \\
\text { Roof } \\
\text { spill } \\
\text { volume }\end{array}$ & $\begin{array}{c}\text { Green } \\
\text { Roof } \\
\text { peak } \\
\text { flow }\end{array}$ & $\begin{array}{c}\text { Green } \\
\text { Roof } \\
\text { spill } \\
\text { volume }\end{array}$ & $\begin{array}{c}\text { Sewer } \\
\text { peak } \\
\text { flow }\end{array}$ \\
& & & & & & & & & & \\
& & & & & & & & & \\
$(\mathrm{l} / \mathrm{s})$ & $\left(\mathrm{m}^{3}\right)$ & $(\mathrm{l} / \mathrm{s})$ & $(\mathrm{l} / \mathrm{s})$ & $(\mathrm{l} / \mathrm{s})$ & $\left(\mathrm{m}^{3}\right)$ & $(\mathrm{l} / \mathrm{s})$ & $\left(\mathrm{m}^{3}\right)$ & $(\mathrm{l} / \mathrm{s})$ \\
\hline 1 & 195.66 & 83.75 & 114.92 & 48.53 & 24.56 & - & - & - & - & - \\
2 & 54.11 & 42.36 & 33.39 & 8.14 & 26.19 & - & - & - & - & - \\
3 & 0 & 0 & 0 & 0 & 2.41 & 0.25 & 2.17 & - & - & 9.58 \\
4 & 0 & 0 & 0 & 0 & 0.82 & 0.06 & 0.46 & - & - & 1.01 \\
5 & 0 & 0 & 0 & 0 & 0 & 0.06 & 0.32 & - & - & 0.18 \\
6 & 433.77 & 28.78 & 131.7 & 9.46 & 8.21 & 0.50 & 18.33 & - & - & 32.40 \\
7 & 0 & 0 & 17.93 & 3.90 & - & 0.08 & 0.50 & - & - & 1.95 \\
8 & 0 & 0 & 0 & 0 & 0.84 & 0.08 & 0.57 & 0.20 & 0.98 & 1.28 \\
9 & 0 & 0 & 0 & 0 & 0 & 0.06 & 0.34 & 0.06 & 0.27 & 0.55 \\
\hline
\end{tabular}


Table 4. Volumetric efficiencies of each pilot SuDS.

\begin{tabular}{ccccccccccc}
\hline Event & $\begin{array}{c}\text { Rainfall } \\
\text { depth } \\
(\mathrm{mm})\end{array}$ & $\begin{array}{c}\text { Runoff } \\
\text { volume } \\
\left(\mathrm{m}^{3}\right)\end{array}$ & $\begin{array}{c}\text { Spill } \\
\text { volume } \\
\left(\mathrm{m}^{3}\right)\end{array}$ & $\begin{array}{c}1 \\
\text { Volumetric } \\
\text { efficiency }\end{array}$ & $\begin{array}{c}2 \\
\text { Runoff } \\
\text { volume } \\
\left(\mathrm{m}^{3}\right)\end{array}$ & $\begin{array}{c}2 \\
\text { Spill } \\
\text { volume } \\
\left(\mathrm{m}^{3}\right)\end{array}$ & $\begin{array}{c}2 \\
\text { Volumetric } \\
\text { efficiency }\end{array}$ & $\begin{array}{c}3 \\
\text { Runoff } \\
\text { volume } \\
\left(\mathrm{m}^{3}\right)\end{array}$ & $\begin{array}{c}3 \\
\text { Spill } \\
\text { volume } \\
\left(\mathrm{m}^{3}\right)\end{array}$ & $\begin{array}{c}3 \\
\text { Volumetric } \\
\text { efficiency }\end{array}$ \\
\hline 1 & 92.0 & 909.0 & 195.7 & $78 \%$ & 598.9 & 114.9 & $81 \%$ & 20.1 & - & - \\
2 & 35.4 & 349.8 & 54.1 & $85 \%$ & 230.5 & 33.4 & $86 \%$ & 7.7 & - & - \\
3 & 23.8 & 235.1 & 0.0 & $100 \%$ & 154.9 & 0.0 & $100 \%$ & 5.2 & - & - \\
4 & 5.4 & 53.4 & 0.0 & $100 \%$ & 35.2 & 0.0 & $100 \%$ & 1.2 & - & - \\
5 & 5.4 & 53.4 & 0.0 & $100 \%$ & 35.2 & 0.0 & $100 \%$ & 1.2 & - & - \\
6 & 119.6 & 1181.6 & 433.8 & $63 \%$ & 778.6 & 131.7 & $83 \%$ & 26.1 & - & - \\
7 & 8.0 & 79.0 & 0.0 & $100 \%$ & 52.1 & 17.9 & $66 \%$ & 1.7 & - & - \\
8 & 9.4 & 92.9 & 0.0 & $100 \%$ & 61.2 & 0.0 & $100 \%$ & 2.0 & 1.0 & $52 \%$ \\
9 & 4.6 & 45.4 & 0.0 & $100 \%$ & 29.9 & 0.0 & $100 \%$ & 1.0 & 0.3 & $73 \%$ \\
\hline
\end{tabular}

Table 5. Mean and standard deviation of quality variables at (31: green roof, 32: conventional roof, 33: rainfall).

\begin{tabular}{lccccccccc}
\hline Quality variable & \multicolumn{3}{c}{31} & \multicolumn{3}{c}{32} & \multicolumn{3}{c}{33} \\
\hline COD $\left(\mathrm{mg} \cdot \mathrm{L}^{-1}\right.$ ) & 292 & \pm & 54 & 35 & \pm & 12 & 11 & \pm & 5 \\
$\mathrm{BOD}\left(\mathrm{mg} \cdot \mathrm{L}^{-1}\right)$ & 16 & \pm & 3 & 10 & \pm & 2 & 5 & \pm & 2 \\
$\mathrm{TN}\left(\mathrm{mg} \cdot \mathrm{L}^{-1}\right)$ & 7.74 & \pm & 1.41 & 3.08 & \pm & 1.26 & 0.86 & \pm & 0.53 \\
$\mathrm{TP}\left(\mathrm{mg} \cdot \mathrm{L}^{-1}\right)$ & 1.84 & \pm & 0.61 & 0.10 & \pm & 0.03 & 0.12 & \pm & 0.12 \\
TSS $\left(\mathrm{mg} \cdot \mathrm{L}^{-1}\right)$ & 26 & \pm & 24 & 9 & \pm & 4 & 6 & \pm & 7 \\
VSS $\left(\mathrm{mg} \cdot \mathrm{L}^{-1}\right)$ & 17 & \pm & 22 & 3 & \pm & 3 & 3 & \pm & 3 \\
Turbidity $(\mathrm{NTU})$ & 18.3 & \pm & 10.5 & 12.1 & \pm & 4.4 & 3.8 & \pm & 3.5 \\
Conductivity $\left(\mu \mathrm{S} \cdot \mathrm{cm}^{-1}\right)$ & 696 & \pm & 131 & 218 & \pm & 19 & 17 & \pm & 5 \\
Temperature $\left({ }^{\circ} \mathrm{C}\right)$ & 21.9 & \pm & 2.5 & 22.1 & \pm & 2.3 & 8.6 & \pm & 8.4 \\
$\mathrm{pH}$ & 7.92 & \pm & 0.27 & 7.57 & \pm & 0.45 & 7.01 & \pm & 0.79 \\
DO (mg $\left.\cdot \mathrm{L}^{-1}\right)$ & 5.72 & \pm & 1.26 & 8.29 & \pm & 0.49 & 9.81 & \pm & 1.56 \\
$\%$ Sat DO & $66 \%$ & \pm & $16 \%$ & $95 \%$ & \pm & $9 \%$ & $99 \%$ & \pm & $2 \%$ \\
\hline
\end{tabular}



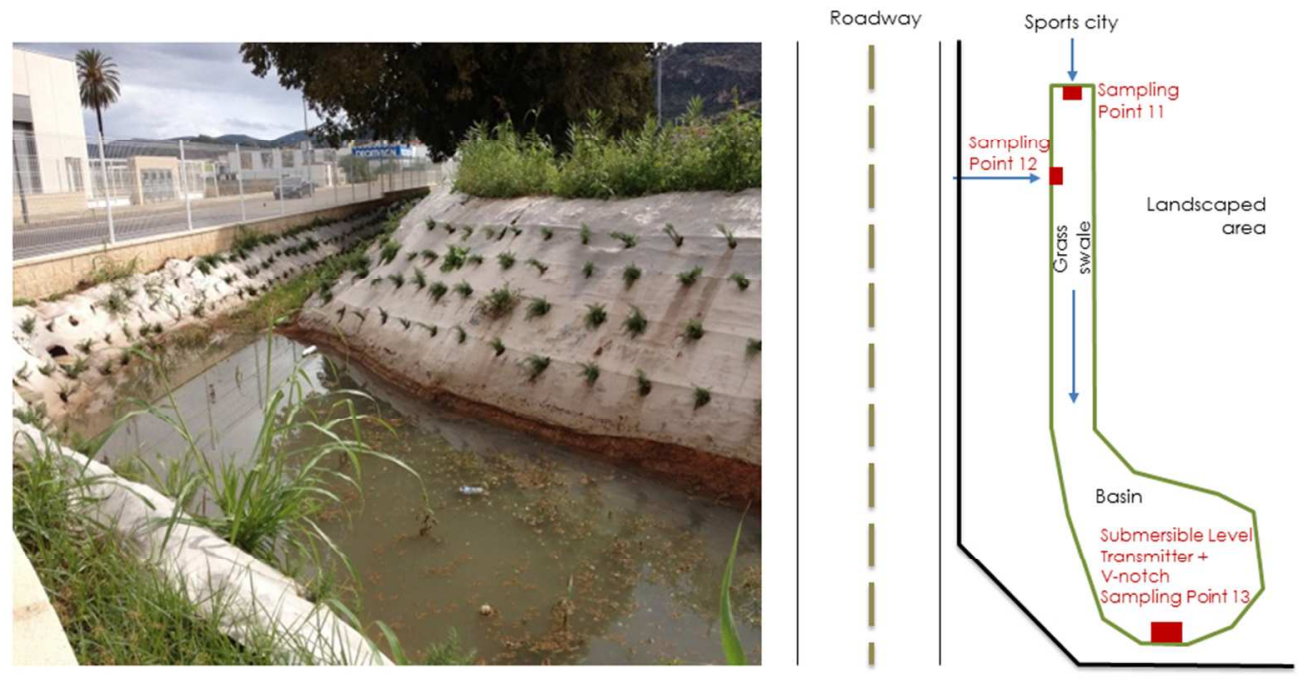

Site 1. Infiltration basin. Photo (left) and monitoring points scheme (right). $254 \times 190 \mathrm{~mm}(96 \times 96 \mathrm{DPI})$ 

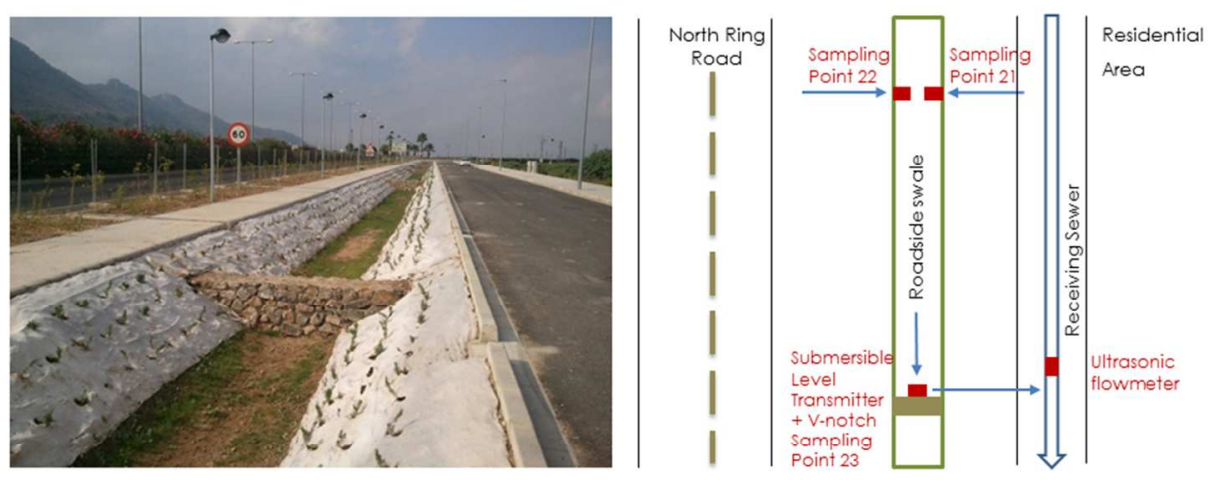

Site 2. Roadside swale. Photo (left) and monitoring points scheme (right). $254 \times 190 \mathrm{~mm}(96 \times 96 \mathrm{DPI})$ 

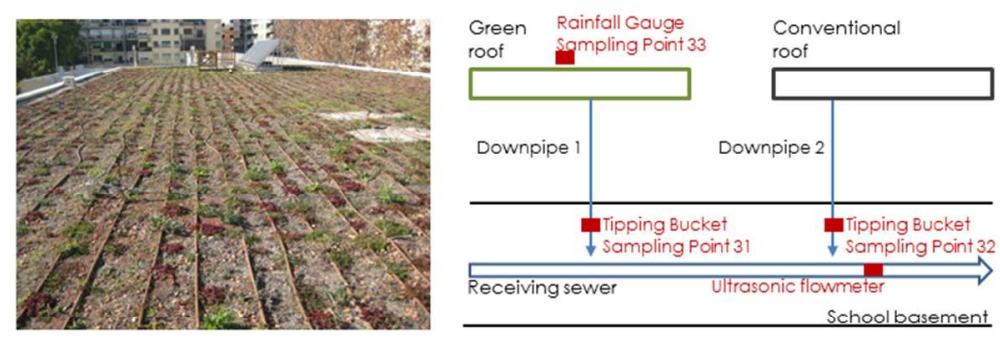

Site 3. Green roof. Photo (left) and monitoring points scheme (right). $254 \times 190 \mathrm{~mm}(96 \times 96 \mathrm{DPI})$ 

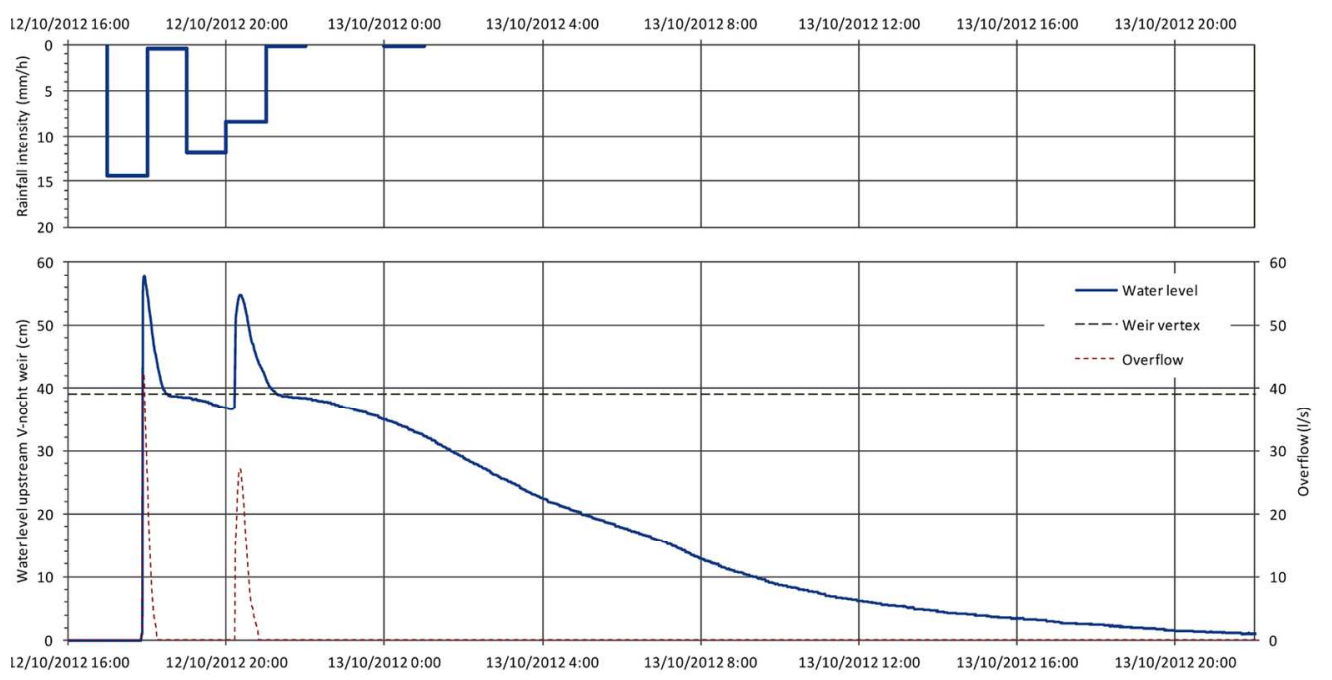

Hydraulic performance for site X1 during event 2 . $69 \times 35 \mathrm{~mm}(600 \times 600 \mathrm{DPI})$ 

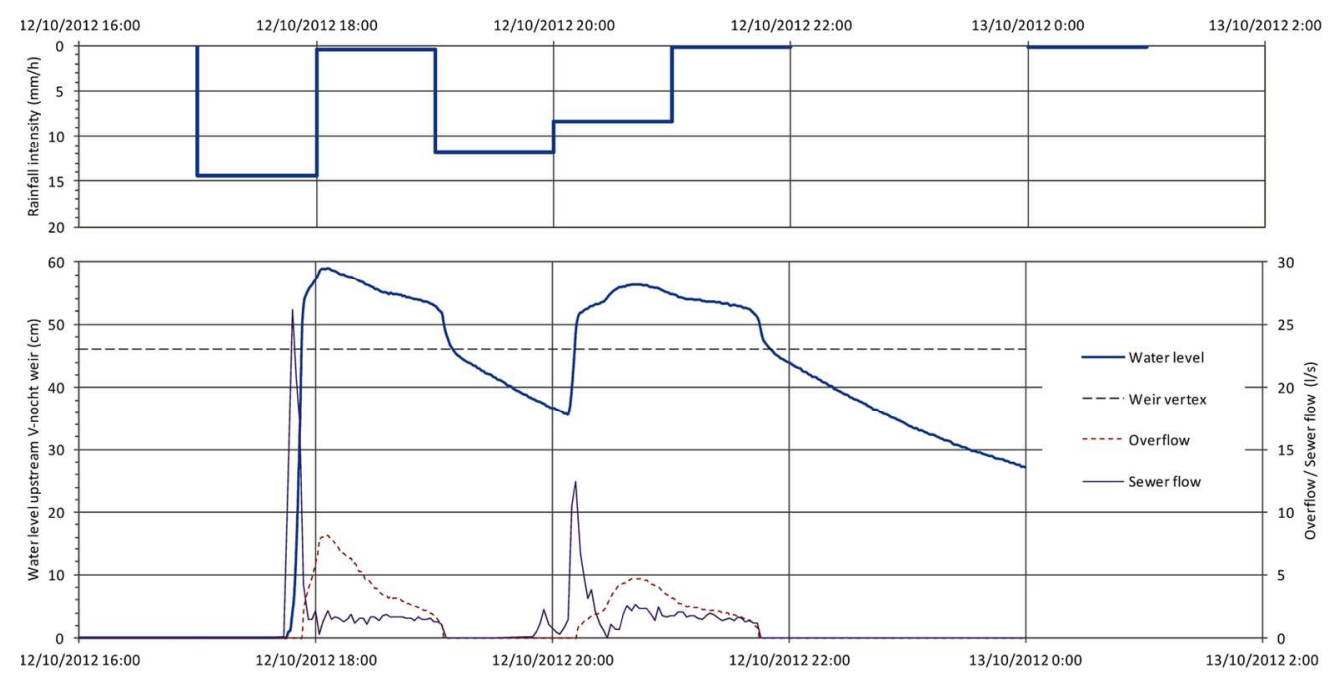

Hydraulic performance for site X1 during event 2 . $68 \times 34 \mathrm{~mm}(600 \times 600 \mathrm{DPI})$ 
Results of quality variables for monitored rainfall events in Sports City green swale (11: Sports City runoff, 12: roadway runoff, 13: green swale output). Columns indicate all rainfall events. The X-axis is time scaled. $254 \times 190 \mathrm{~mm}(96 \times 96 \mathrm{DPI})$ 
Results of quality variables for monitored rainfall events in the North Ring Road grass swale (21: residential area runoff, 22: roadway runoff, 23: grass swale output). Columns indicate all rainfall events. The $X$-axis is time scaled. 